\title{
LIBERALIZATION OF EU GAS SECTOR: IMPACTS AND PERSPECTIVES FOR FU'TURE DEVELOPMENT
}

\author{
Ljerka Cerović ${ }^{1}$, Marko Donadic ${ }^{2} \&$ Tomislav Galović ${ }^{3}$
}

\author{
UDK/UDC: $620.9(4$ 67EU):665.612 \\ JEL classification / JEL klasifikacija: $\mathrm{L}_{95}$
}

Review / Pregledni rad

Received / Primljeno: April 12,2009/12. travnja 2009.

Accepted for publishing / Prihvaćeno za tisak: June 15, 2009 / 15. lipnja 2009.

\section{Summary}

The paper summarizes liberalization and EU gas market opening along with its prospects and forecasts. In order to establish a single European gas market, EU Directives must be observed. Furthermore, the objective of Europe's energy policy is the provision of sustainable, secure and competitive energy to European consumers. The European gas sector is committed to ensuring that natural gas - with strong environmental advantages - is able to play its full part in a competitive, secure and sustainable energy sector. As regards competitiveness, the European gas sector is ensuring a competitive and non-discriminatory energy market, within which gas plays an important part. A successful internal market is essential to the competitiveness of Europe and contributes to investment in infrastructure to support supply security, efficiency and service. In a competitive energy market, environmental concerns are addressed through market-based instruments. The paper also contains an analysis of the recent changes in the structure of gas demand and supply and its consequences for enhancing the competition in the EU gas market. It discusses the role of growing gas demand, taxation of gas production and trade along with the dependency of the EU gas sector. Liberalisation of the gas market is a very important tool which contributes to the development of the European economy, in order to achieve its goals of efficiency and competitiveness in an ever-increasing global marketplace. Clearly, the implementation of the EU Gas Directive can be viewed as a final step by the EU to accomplish an internal market for gas. The major objective is to promote increasing competition in the natural gas market, and

Ljerka Cerović, Ph.D., Assistant Professor at the Faculty of Economics in Rijeka, E-mail: cerovic@efri.hr

2 Marko Donadić, M. Sc., International Relations Assistant at the Faculty of Economics in Rijeka, E-mail:mdonadic@efri.hr

3 Tomislav Galović, Junior Assistant at the Faculty of Economics in Rijeka, E-mail: tgalovic@efri.hr 
to reduce gas prices for all customers and thereby to increase the competitiveness of (energyintensive) European industries and economies. Moreover, this paper discusses prospects for increased consumption of natural gas and future trends of the European gas market within the European Union (EU) up to 2030, presuming that the liberalization effects can provide positive results on functioning of the European Gas Sector and thus contribute to a much lower increase in gas prices.

Key words: EU gas sector, European gas market liberalization, development of European gas sector, EU energy policy.

\section{INTRODUCTION}

The EU gas sector plays a vital role by being a valuable initiator of European economic development. The extreme importance of gas as an energy source has been proved by recent events which resulted in a break in gas supply from Russia and Ukraine to the EU. Europe and especially transition countries felt the biggest impact of the gas crisis in the beginning of 2009. Companies' losses that were counted in billions are indisputable evidence of EU's gas dependence. Furthermore, restrictions on $\mathrm{CO}_{2}$ emissions, the nuclear phase out announced by some member states, high emissions from coal based generation, and barriers to rapid development of renewable generation are evident factors that seem to force the $\mathrm{EU}$ to be highly dependent on natural gas. EU is facing a growing dependency on foreign regions not only for the supply of oil but also for the supply of gas. The situation is further complicated by large investments that will be needed and uncertain investment conditions that prevail in some of the regions targeted to cover the future EU gas demand.

Natural gas accounts for a relatively large share of Europe's energy consumption, and with global reserves for over 60 years its market share is expected to continue to grow. Gas has long been the fuel of choice because of the efficiency in this form of energy distribution, its flexibility and control of its use, its low emissions of $\mathrm{CO} 2$ and low levels of pollutants. These qualities make gas attractive for direct use in homes and businesses.

In order to take advantage of these gas features, the EU should create a proper atmosphere in order to give momentum to liberalization. However, there are multiple complications which make liberalization much harder. The European Union is facing numerous problems in its gas market. High concentration rate with a few large firms dominating the market, high degree of "vertical integration" whereby a single company controls all stages of the production and distribution of gas, and market fragmentation along national lines are still obstacles which EU needs to cope with. Some problems are effectively solved but some still exist due to unforeseen deviations in market functioning. Therefore, the basic hypothesis of this study is that liberalization effects can provide positive results on the functioning of the European gas sector and could contribute to a slower increase in gas prices.

After these introductory remarks, the second part of this study discusses the role of the EU gas sector within the EU Energy policy. The third part focuses on European gas 
market liberalization and its impacts. The fourth part contains an analysis of the recent changes in the structure of the gas demand and supply and its consequences for increasing competition in the EU gas market. 'The final part of this study outlines prospects for increased consumption of natural gas within EU up to 2030 and other indicators which measure the general condition of the EU gas market in near future. The overall objective of this study is to define EU gas market liberalization effects and to detect problems that make liberalization less efficient in terms of a better perspective for the European gas sector.

\section{ROLE OF THE EU GAS SECTOR WITHIN EU ENERGY POLICY}

The process of liberalizing electricity and gas markets started about 10 ycars ago. During these 10 years, many of Europe's citizens have benefited from more choice and more competition, with improved service and security. 'The assessment carried out by the Commission and Europe's energy regulators has however demonstrated that the process of developing real competitive market is far from complete. The goal of Europe's energy policy is the provision of secure, competitive and sustainable energy to European customers. The role of this paper is to show how natural gas can contribute to achieve three aims - sustainability, competitiveness and supply security within a balanced energy policy framework (Eurogas Position Paper, 2008):

As regards competitiveness, the EU gas market is committed to ensure a competitive and non-discriminatory energy market, in which gas is an important component. A successful internal market is essential to the competitiveness of Europe, and contributes to give incentives to investment in infrastructure in order to support supply security, efficiency and service. In a competitive energy market, environmental concerns are readily addressed through market-based instruments.

When it comes to supply security, diversity of the sources of energy is the best means of ensuring that Europe continues to have access to the energy it needs. This requires full exploitation of Europe's indigenous energy sources with renewables and new technologies as supporting instruments until they are established, although it is essential that such support in the initial stages does not distort market competition.

As regards sustainability, natural gas as the most environmentally friendly fossil fuel can make a major contribution towards Kyoto objectives and beyond. New gas technologies and applications play a major part in meeting the challenges of climate change - through high efficiency boilers and appliances, in power generation (including $\mathrm{CHP}$ ) and in applications such as road transport.

These comparative characteristics of strong environmental advantages are wellpositioned in the policy debate, and capable of playing its full part in a competitive, secure and sustainable energy sector. In practice, far too many EU citizens and businesses are lacking a real choice of supplier. Market fragmentation along national borders, a high degree of vertical integration and high market concentration are the root cause why the internal market has not really been completed (Proposal for Directive 2003/55/EC, 2007). 
The single market for gas will, gradually, produce a competitive and vibrant gas market across the European Union. Its main goal is to contribute to the achievement of the three main EU energy policy objectives of increased competitiveness through better service for energy consumers, security of supply, and protection of the environment including meeting the EU's Kyoto commitments to reduce emissions of greenhouse gases such as carbon dioxide $\left(\mathrm{CO}_{2}\right)$.

In November 2005, the European Commission published its first major review of the market liberalization process, and was highly critical of the slow progress towards an open, competitive market shown by many member states (Jackson and Harris, 2008). At the same time, the EC competition authorities launched an enquiry into the energy sector, publishing scathing observations on the lack of real competition in the gas market and identifying enormous barriers to entry for new gas suppliers.

The EU has detected that reliable energy supplies are vital for European consumers, for the competitiveness of its industry and for a well-functioning society (Kjärstad and Johnsson, 2008:877). In October 2000, the EU-Russia Energy Dialogue was initiated, in June 2003 a series of guidelines for Trans-European energy networks (TEN-E) were put forward in a decision by the European Parliament (1229/2003/EC) and the Directive 2003/55/EC concerning common rules for the internal gas market was adopted. However, in June 2005, the commission opened an inquiry into the functioning of the internal gas market caused by recent dramatic increases in gas and electricity prices and numerous complaints about various barriers to entry. The inquiry was published in November 2005 concluding that the progress of liberalizing the internal gas market had not moved forward as rapidly as predicted and wanted with respect to market concentration and market integration as well as transparency. Perhaps most relevant, the inquiry concluded that there were no clear trends towards more market based pricing mechanisms (European Commission, 2005).

These reports will give new resolve to the enforcement of competition rules by both European and national regulators. The expectations are that few of the key barriers faced by new market entrants will now be removed, giving an enormous boost to the development of gas trading, especially in the key German market. The temporary conclusion is that liberalization is not completely meeting expectations.

Do these facts make people think that liberalization can be $100 \%$ efficient? Obviously not, because in the past few years, gas prices have been dominated by two factors - the rising price of oil and the declining EU production of gas. It is very complex to predict the trend of oil prices which are directly linked to the level of gas prices. Comparative advantages of gas as an energy source in the framework of energy policy have already been mentioned. These advantages should systematically give impetus to creating the EU gas sector, mitigating all its negative effects through the liberalization process.

\section{OPENING OF THE EUROPEAN GAS MARKET}

First usage of gas stared to change the European energy balance in the $60 \mathrm{~s}$, particularly in the Netherlands and the UK, because of its large domestic resources. Until the 
end of the 80 's, European gas policy was focused mainly on limiting the use of natural gas for electricity generation and promoting extraction of gas in the Community. This was to secure the availability of sufficient natural gas to 'highly valued' (small) consumers. Until 1990, the issue of gas market liberalization did not feature significantly on the policy agenda of the European Commission. Its concerns were focused primarily on issues of security of its supply. The gas industry was allowed to operate according to the individual wishes of each Member State government. Perhaps because of the strategic importance of energy supply, no serious attempts were made to establish a free market in either gas or electricity, in spite of the EU objective to establish a free market for other goods and services. In 1988, the Commission published the white paper entitled 'The Internal Energy Market' with the aim of EU Member States establishing a single market for energy by 1992. Clearly, the realization of a single market for energy presented more serious obstacles than for other commodities. From that point on, liberalization of gas and electricity markets has held an important place on the Commission agenda. The first relevant directive was adopted in 1990 and pertained to price transparency for industrial gas prices. Member States were required to inform the Commission about gas prices under clearly defined categories. The Price Transparency Directive and the gas and Electricity Transit Directive of 1990 could be regarded as first, preliminary steps to the opening-up of the European energy markets to competition. The Transit Directive enabled nominated gas companies to use the pipelines of other nominated gas companies, provided that gas crosses an internal European border. During 1991, the Commission started to work on its main proposal for the realization of a true internal energy market, which was stimulated by developments in the UK, where the liberalization of gas market was started. Discussion on liberalization of the gas markets in the EU continued, and after several years of debate a political agreement on a new EU Gas Directive was finally reached in December 1997. After being adopted by the Energy Council with a unanimous common position, the EU Gas Directive was finally approved by the European Parliament in June 1998 and entered into force on August 1998 (Van Oostvoorn and Boots, 1999:7-8).

The EU Gas Directive aimed to create a full competitive market in natural gas thro ugh common rules for transmission, distribution, supply and storage. Central to this aim was the requirement to open up the transmission network and storage facilities to third party access, so that eligible customers can buy gas directly from producers if they wish. The Directive established minimum degrees of market opening and also allowed new entrants to build pipelines (Van Oostvoorn and Boots, 1999:5). Thus, since 1998, things have been moving fast. Member States have prepared the implementation of the gas directive to allow competition and market opening to take effect as of 10 August 2000, the date by which Member States had to transpose the directive into national legislation. This date was a milestone in this process and is marked as the beginning of a new era in European gas market development and represented a fundamental change in the organization and operation of the European gas market. The basic objective of the internal market for natural gas, as in all other sectors of the European economy, was to create one large, single market in Europe by integrating national markets, which have hitherto been compartmentalized in separate markets typically dominated by one or a few players. In order to achieve a fully operational internal market in the gas, electricity and other sectors, the European Council 
asked the Commission, Council and Member States 'to speed up liberalization' in these sectors (European Commission, 2000).

By opening up national markets to competition and by integrating the 15 national gas markets into one single market, free of artificial obstacles to cross-border trade, wide scope for gas-to-gas competition was created. Customer choice was the key to competition. As of 10 August 2000, the so-called 'eligible customers' were free to choose their gas supplier. In order to be effective, this freedom of choice of supplier required non-discriminatory access to the gas network throughout Europe. By empowering the consumer through customer choice, it gave a push to many effects as it pressured all the operators along the gas chain to improve customer service, cut costs and reduce prices. Opportunities for new entrants into the gas market increased this pressure to the advantage of customers. So, new entrants were enabled to trade in the internal gas market and to embark on new infrastructure projects, hence expanding and diversifying supply capacity and enhancing the security of supply (European Commission, 2000).

The key element of gas market liberalization was giving eligible customers the freedom to choose their gas suppliers. The Gas Directive allowed member states to attain this goal through phasing in the market opening in three main phases (European Commission, 2000:6):

Phase 1: At least all gas-fired power generators, irrespective of their annual consumption level and all other final customers consuming more than 25 million $\mathrm{m}^{3}$ per year shall be specified as eligible customers as from 10 August 2000. Market opening in phase 1 shall be at least $20 \%$.

Phase 2: At least all gas-fired power generators, irrespective of their annual consumption level and all other final customers consuming more than 15 million $\mathrm{m}^{3}$ per year shall be specified as eligible customers as from 10 August 2003. Market opening in phase 2 shall be at least $28 \%$.

Phase 3: At least all gas-fired power generators, irrespective of their annual consumption level and all other final customers consuming more than 5 million $\mathrm{m}^{3}$ per year shall be specified as eligible customers as from 10 August 2008. Market opening in phase 3 shall be at least $33 \%$.

As expected, the level of market opening from 10 August 2000 onward was much higher than a minimum of $20 \%$, which the EU Gas Directive has required at the beginning of market opening.

As shown in Table 1, for those Member States for which data was available, the degree of market opening either increased significantly between 2001 and 2005 or was already $100 \%$ in 2001 . Big changes were recorded, particularly for the main contributing countries like Spain, France and Italy. In some cases, full liberalization was achieved. By September 2005, full market liberalization for both industry and households was completed in ten Member States for electricity and in seven Member States for gas. Denmark, Germany, Spain, the Netherlands, Austria and the UK had fully liberalized markets for both electricity and gas (Urbanski, 2006:6). 
Table 1: Evolution of market opening in gas and electricity markets between 2001 and 2005

\begin{tabular}{|c|c|c|c|c|}
\hline & Heec & ricity & & \\
\hline & 2001 & 2005 & 2001 & 2005 \\
\hline Belqium & $35 \%$ & $90 \%$ & $59 \%$ & $90 \%$ \\
\hline GechRepublit & 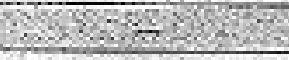 & $74 \%$ & $=$ & $25 \%$ \\
\hline Denimark & $90 \%$ & $100 \%$ & $30 \%$ & $100 \%$ \\
\hline Germany & $100 \%$ & $100 \%$ & $100 \%$ & $100 \%$ \\
\hline Fstrnia & & $12 \%$ & - & $95 \%$ \\
\hline Greeco & $30 \%$ & $62 \%$ & 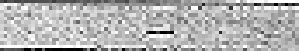 & 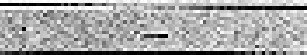 \\
\hline Spain & $15 \%$ & $100 \%$ & $72 \%$ & $100 \%$ \\
\hline Trance & 3036 & $70 \%$ & $203 \%$ & $10 \%$ \\
\hline Treland: & $30 \%$ & $700 \%$ & $75 \%$ & $86 \%$ \\
\hline ftaly & $45 \%$ & $79 \%$ & $65 \%$ & $100 \%$ \\
\hline Gyprus & & $35 \%$ & & - \\
\hline Latwa & -3 & $76 \%$ & -3 & 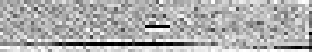 \\
\hline Lithuania & - & $74 \%$ & & $90 \%$ \\
\hline lixicmbourd & $-x$ & $84 \%$ & $51 \%$ & $.80 \%$ \\
\hline Hunqary & - & $67 \%$ & $=$ & $66 \%$ \\
\hline Malfa & & 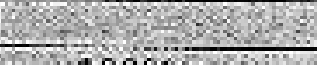 & -5 & 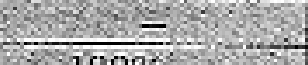 \\
\hline Netherlands & $33 \%$ & $100 \%$ & $\frac{45 \%}{40 \% \%}$ & $\frac{9009}{100}$ \\
\hline Austria & $100 \%$ & $100 \%$ & $49 \%$ & $100 \%$ \\
\hline Poland & -4 & $80 \%$ & 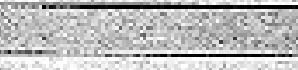 & $72 \%$ \\
\hline Portugal & $30 \%$ & $\therefore 100 \%$ & - & $=9$ \\
\hline Slovenia & 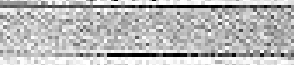 & $71 \%$ & - & $91 \%$ \\
\hline Slovakia: & - & $79 \%$ & - & $72 \%$ \\
\hline Finland & $100 \%$ & $100 \%$ & $100 \%$ & $x_{0}-5$ \\
\hline Sweden & $100 \%$ & $100 \%$ & $47 \%$ & $95 \%$ \\
\hline United Kini & $100 \%$ & $300 \%$ & $100 \%$ & 100 \\
\hline
\end{tabular}

Source: Urbanski, T. (2006), Energy production and distribution enterprises in the EU, European Communities: Statistics in Focus - Industry, Trade and Services, No. 31, p. 6

\section{ANALYSIS AND MAIN INIICATORS OF THE EU GAS SECTOR}

Natural gas currently occupies a $24 \%$ share of Europe's energy consumption and with global reserves for over 60 years its market share is expected to continue to grow. Gas has long been the fuel of choice because of the efficiency in this form of energy distribution, flexibility and control of its use, its low emissions of $\mathrm{CO}_{2}$ and low levels of pollutants. These characteristics make gas attractive for direct use in homes and businesses, in centralized power generation and - in some member states - in the transport sector. The focus of the analysis is from now on put on growing gas demand, gas supply, and the European gas dependency based on import and export values.

\subsection{EU gas demand}

After a period of sluggish growth in the 1980 's the demand for natural gas within the European Union is projected to rise gradually over the coming decades. Natural gas demand is said to be 'booming' all over Europe. The all-around optimism is fed by a number of structural economic and political developments. The main factors that have been blocking the use of natural gas are either no longer present or will be lifted within the foreseeable future. First, it has become clear that natural gas reserves, both on a European as well as on a world scale, are abundant. Hence, it appears no longer necessary to restrict the use 


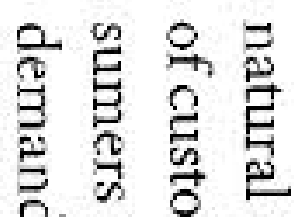
돈영

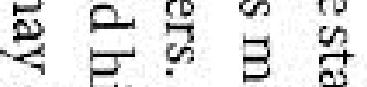

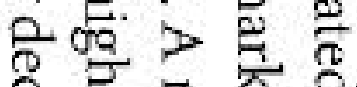
气 쿵

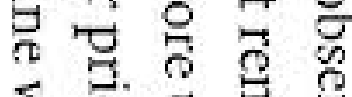
芯䒠总 क 今寻 寻

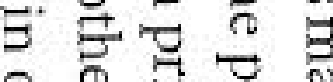
오용 붕

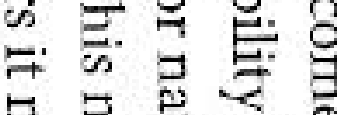

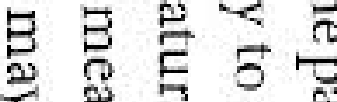

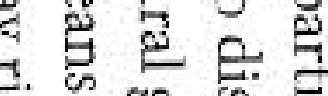
今 哭气 ह 콜

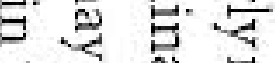
宁 $\exists \stackrel{0}{0}$ 总怘总. 马 क ๑ 今

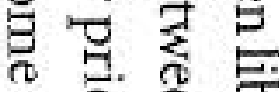
छ $\overparen{0}$

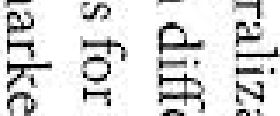
अ

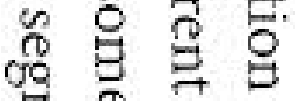

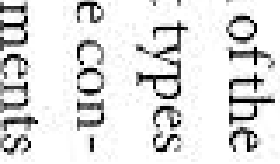

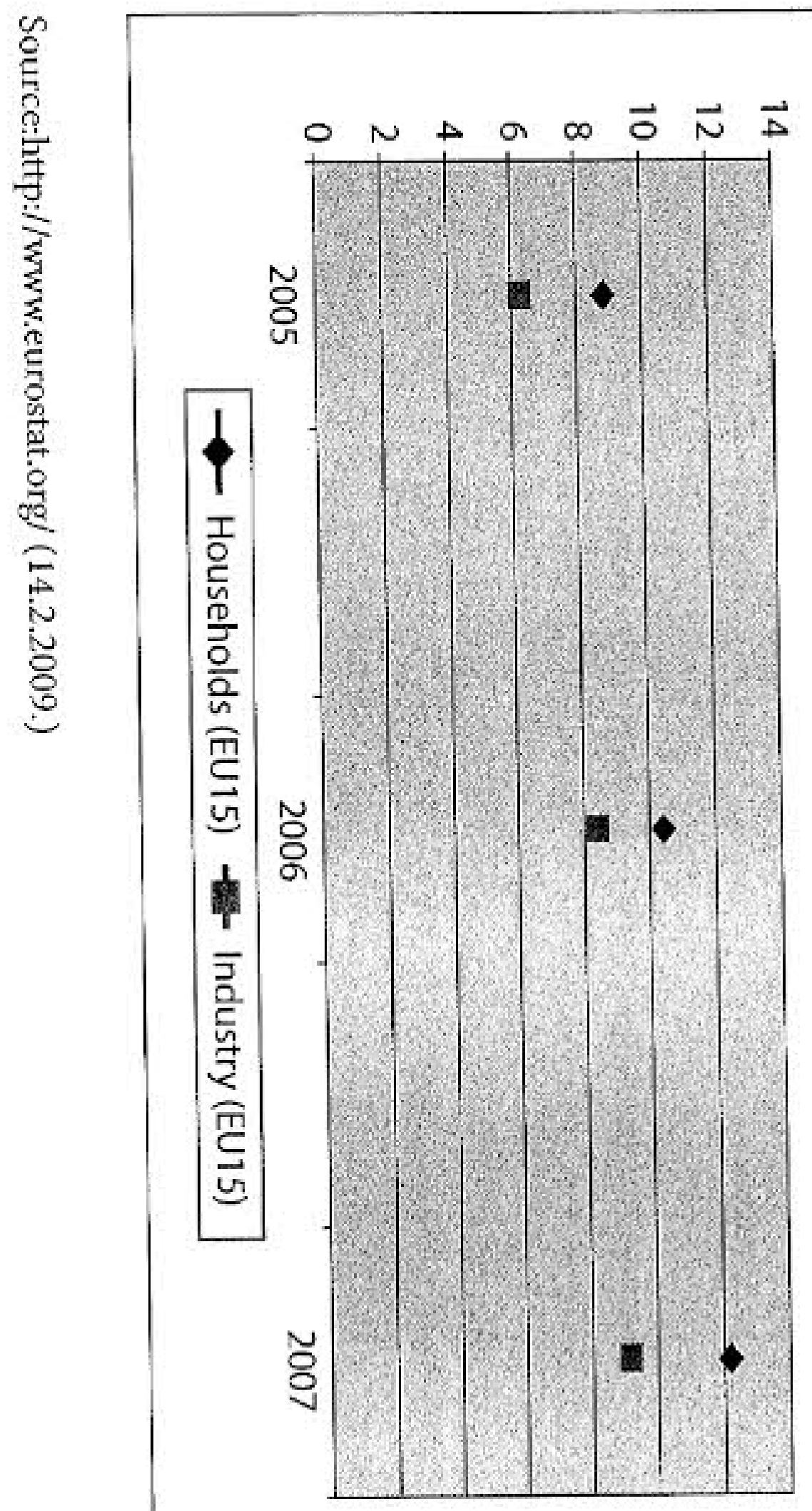

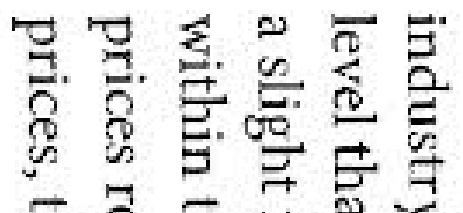

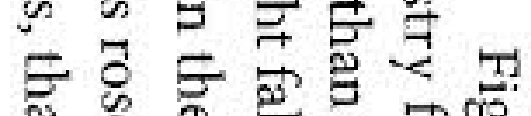

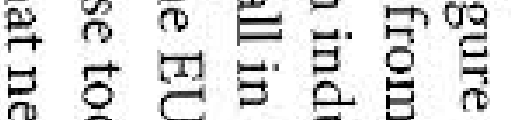
¿ 可哭

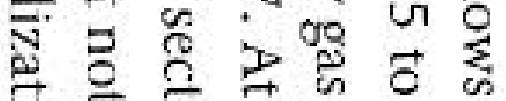

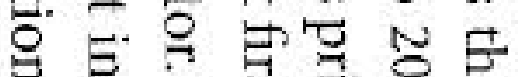

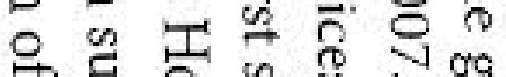

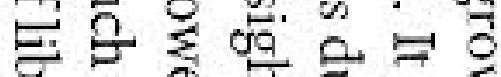

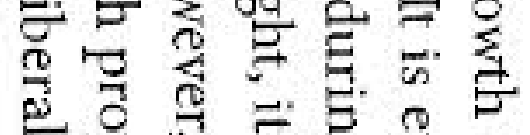

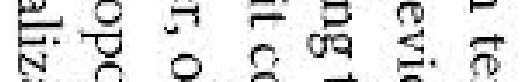

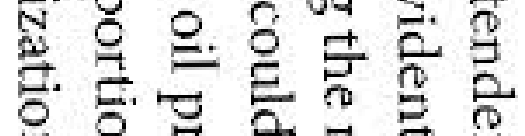

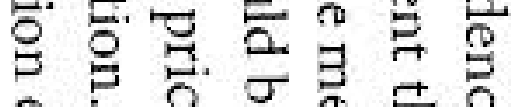
ช.

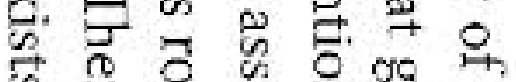
要

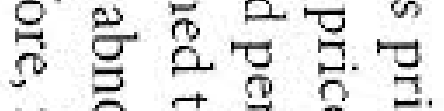
$\Rightarrow$ 홍요

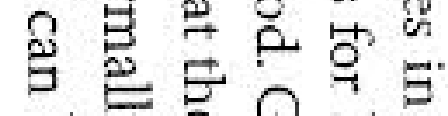

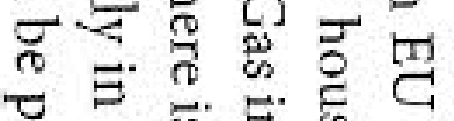

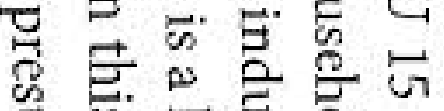

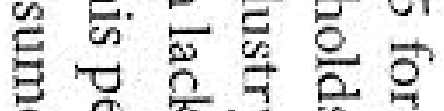

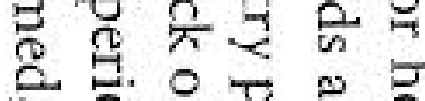

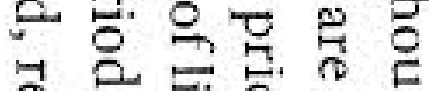
总

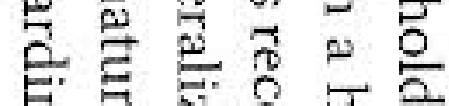

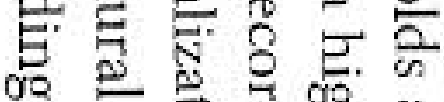

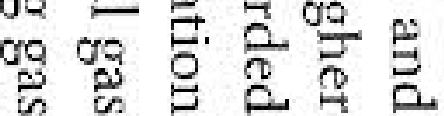

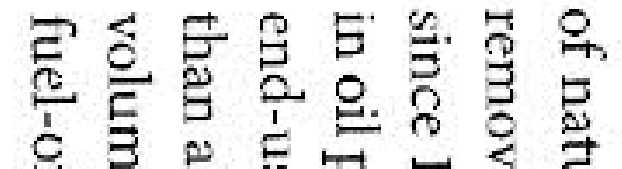

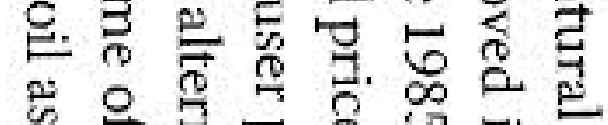

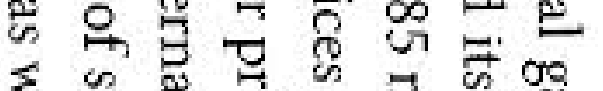
๙

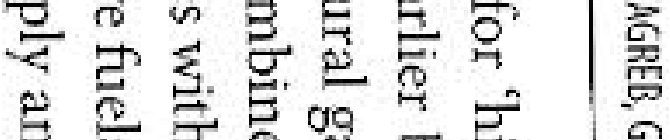

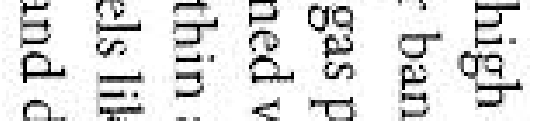

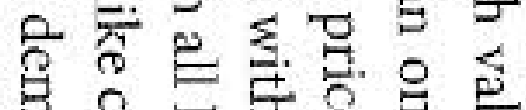

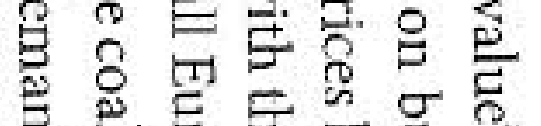

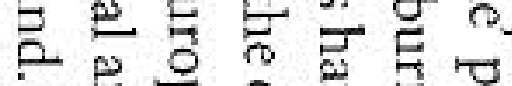

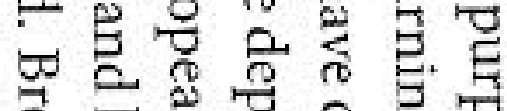

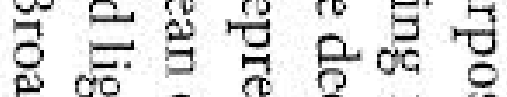

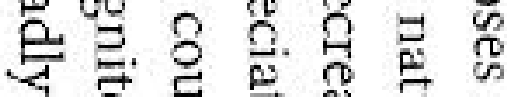

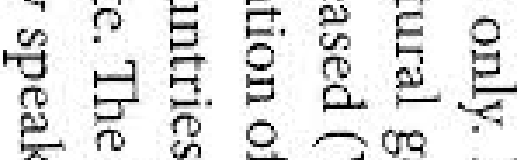

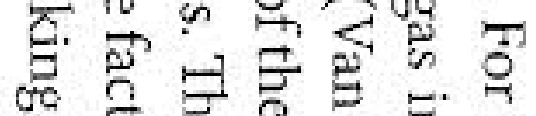

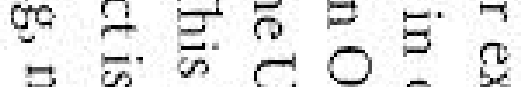

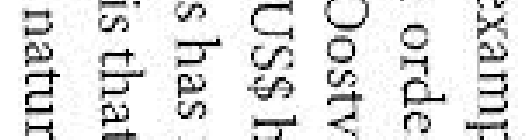

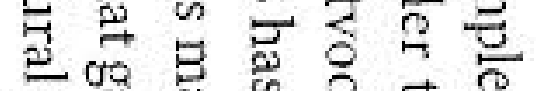

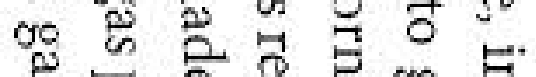
क क

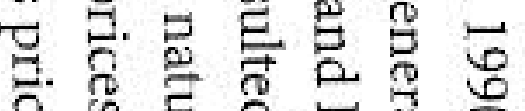

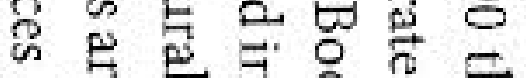

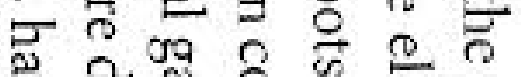
বेक्ष

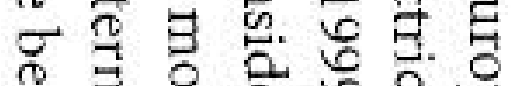

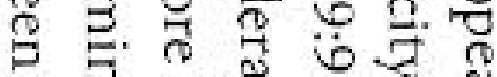
西恕焉的

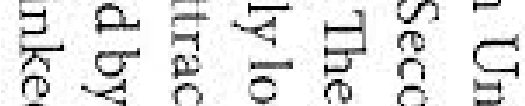

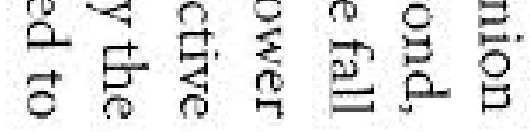




\subsection{EU gas supply, net imports and dependency}

The ownership structure on the supply side of the European gas market can be characterized as an extremely complex oligopoly. In order to limit market risk, the search for and exploration of (new) gas fields is often executed in joint ventures with other gas companies. Although the operation of a single gas field usually rests with one company, all partners in the joint venture are entitled to a part of the profit (loss) of the gas field in question. Additionally, many upstream companies have extensive interests in the downstream part of the market. The prime example is Shell, which holds an interest in at least 15 different transmission companies (Van Oostvoorn and Boots, 1999:18). The upstream market is the most competitive part of the natural gas chain. About twenty major companies are involved in the exploration and production of the natural gas for supply to seven major consumer countries in the EU (Austria, Belgium, France, Germany, Italy, Netherlands, and UK). Additionally Figure 2 shows EU-27 gas suppliers in 2007. According to Eurogas, the European natural gas trade association, the EU- 27 covered $38 \%$ of its gas needs with its own production, mainly from the UK and the Netherlands. The EU's principal external suppliers are Russia ( $24 \%$ of final EU consumption), Norway (17\%) and Algeria (9\%). However, the situation deviates widely throughout the EU, with Central and Eastern European member states often heavily dependent on Russian imports. This is the case for Bulgaria, Slovakia, Austria, and Greece, but also the Baltic States and Finland, where Russian dependency can reach $100 \%$. Others, on the other hand, import no Russian gas at all. These include Belgium, Ireland, Portugal, Spain, Sweden and the UK.

Figure 2: Gas suppliers in 2007

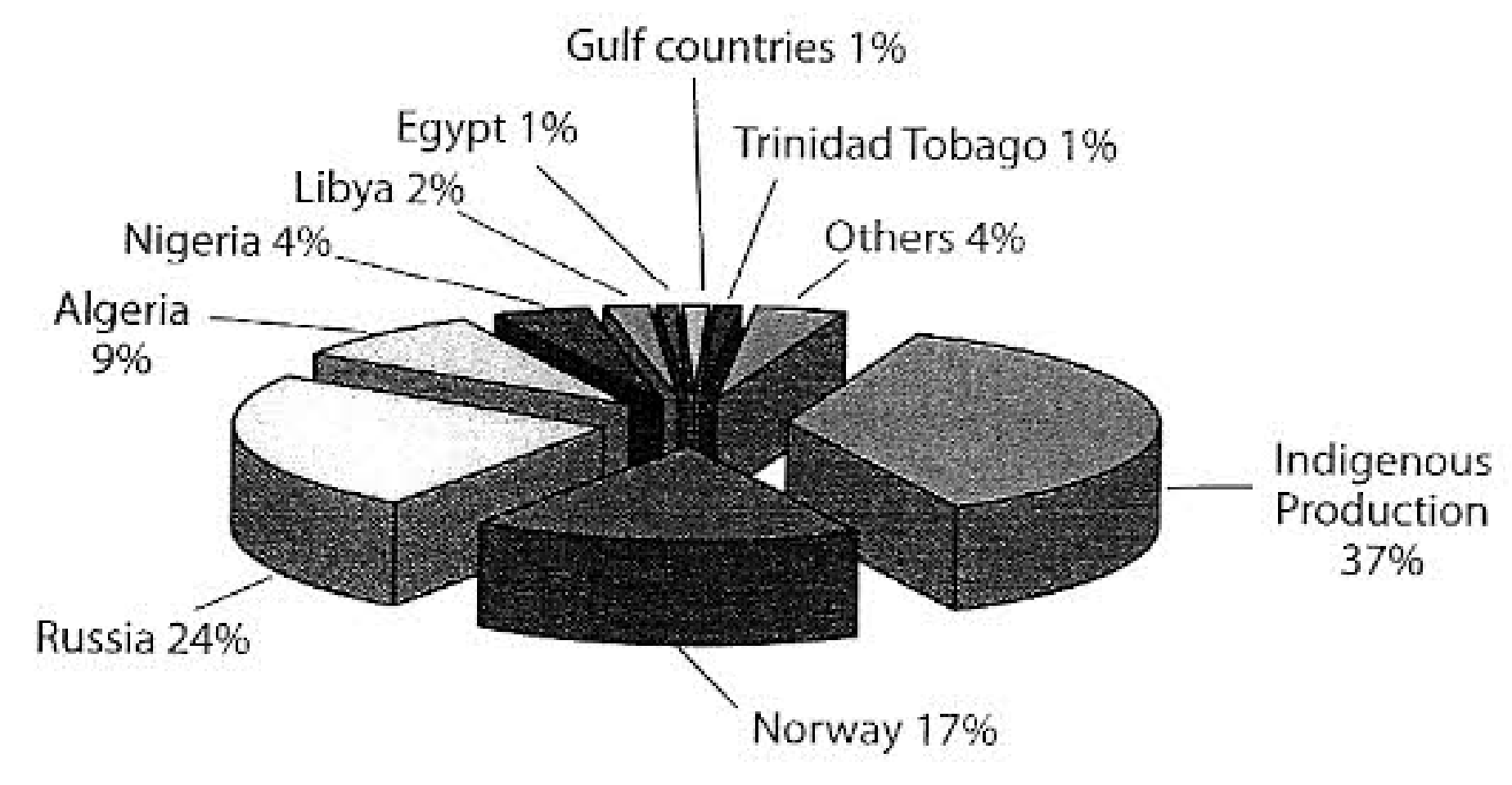

Source: http://www.eurogas.org/ (14.2.2009.) 
Unlike oil, which can be transported easily in tankers, gas is still transported mainly via pipelines, making Europe dependent on cxisting supply and transit routes. The need for Europe to diversify supplies was underlined by a dispute between Ukraine and Russia in January 2006, which led to interruptions to supplies of Russian gas for some EU states. Some $80 \%$ of Russian gas transits Ukraine. In the wake of the dispute, EU states agreed to speed up a number of projects, including (Euractiv article, 2008):

- The Nabucco pipeline, which will allow Europe access to large gas fields in the Caspian region and the Middle East.

- Building new terminals for Liquefied Natural Gas (LNG) that can be transported by ship to regions where pipeline connections are not feasible.

These steps towards fulfilling the main objectives of the single gas market could reduce European gas dependency and make liberalization more efficient in order to initiate a fall in gas prices. Figure 2 shows EU-27 natural gas dependency in 2005.

In 2005, the EU-27 encrgy dependency rate for natural gas was $57.7 \%$, an increase of 14.1 points compared to 1995 . While the primary production of EU-27 natural gas remained stable, the Gross Inland Consumption increased by one third compared to 1995. This increase is compensated by the increase in imports by $77 \%$. The top 3 import countries (Germany, Italy and France) increased their imports by $53 \%$ compared to 1995 . In addition, the Spanish market with 8.3 Mtoe net natural gas imports in 1995 grew intensely by a $15 \%$ average annual rate to $34 \mathrm{Mtoe}$, to hold a $12 \%$ share of EU total imports in 2005 . The Netherlands and Denmark are the only EU-27 natural gas exporting countries, with energy dependency ratio of $59 \%$ and $114 \%$ respectively. The net exports of these countries amounted to 29 Mtoe, 23 for the Netherlands and 6 for Denmark. Apart from the two net exporters mentioned above, the UK, Poland and Romania, the remaining Member States have an energy dependency rate for natural gas higher than $80 \%$. In order to calculate natural gas dependency the unavoidable subsection called "net imports" must be taken into consideration. Hereby, Figure 3 shows the status of EU-25 and EU-27 net imports of natural gas.

According to Eurostat, natural gas net imports continue to maintain an average annual increase of $6 \%$, having risen by $77 \%$ since 1995 . Of the three traditional North Sea producers (DK, NL, UK), the United Kingdom has recently become a net importer and the Netherlands have reduced their annual exports while Denmark on the other hand has expanded their net exports more than 3 times between 1995 and 2005. Germany, France and Italy remain the largest importers of EU-27. Nevertheless, their total net imports share dropped from 75 to $65 \%$ within the period 1995-2005 despite substantial growth in net imports, since in the same period other countries have expanded their consumption. One of the objectives of liberalizing the EU gas market is the security of gas supply. It is evident that most EU Member States are dependent on gas and they are exposed to external influences. 'The effects of liberalization will be effective when the gas dependency of EU countries is reduced to a certain level. As a result, there will be a stronger impact on prices or on the production and consumption of the EU economies. 
Figure 3: Natural gas dependency in 2005 (in \%)

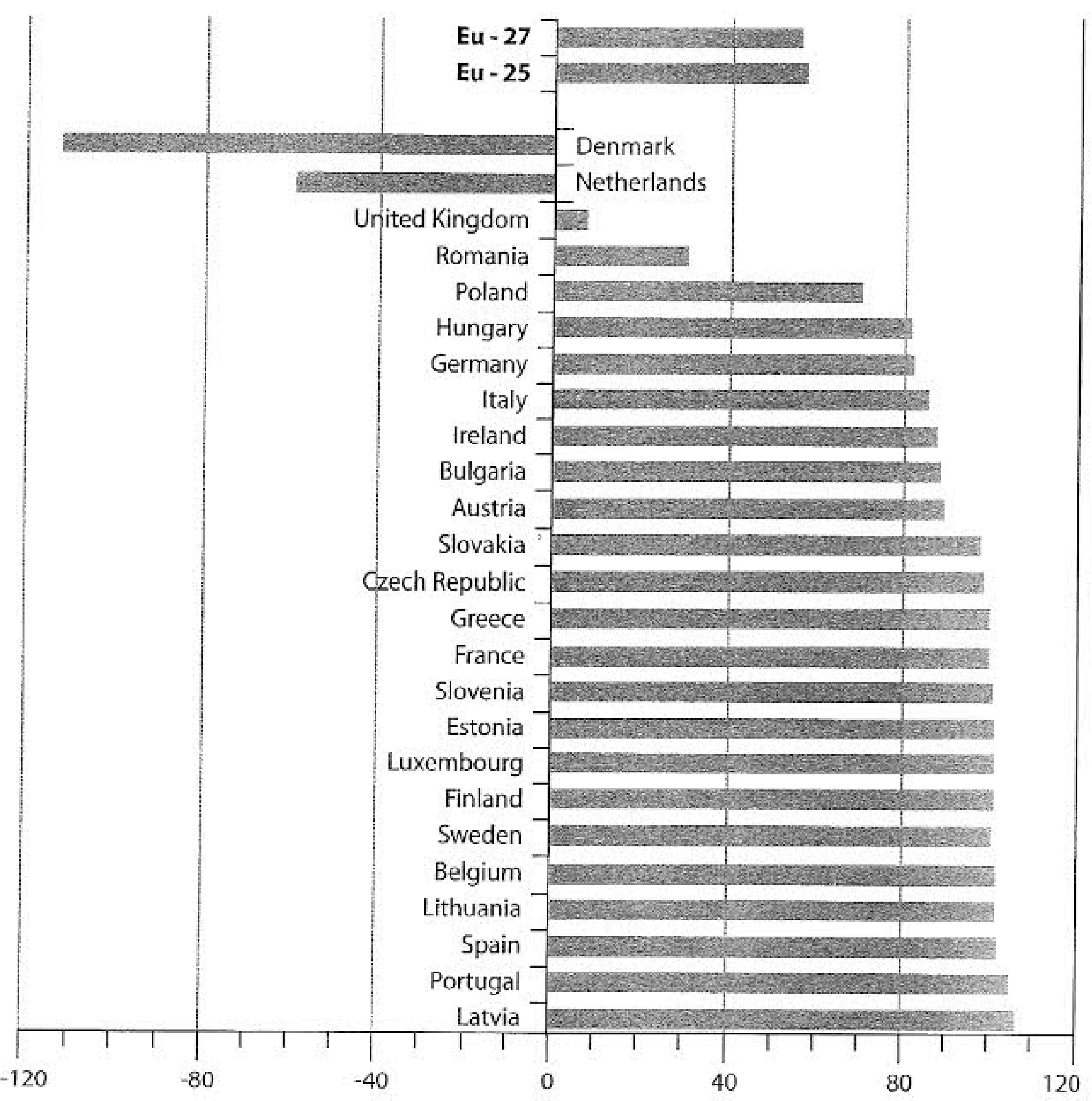

Source:http://www.eurostat.org/ (14.2.2009.)

\section{THE PERSPECTIVE FOR FUTURE DEVELOPMENT OF EU GAS SECTOR}

Viewed in the long term, the gas sector will play an increasingly important part in the supply of energy. Higher demand for gas will result in higher gas prices. If EU's energy dependence on gas is reduced and if the prerequisites for liberalization of the EU gas sector are created, then we can expect a smaller price increase. In the short term, the global world crisis and the slowing down of the world economy will affect the reduced growth caused by price reduction in oil prices. 


\subsection{The perspective for gas demand}

Different visions of the future of the EU gas sector are predicted. According to Eurogas predictions from 2007 , the factors determining future energy demand in the EU-27 include: continued economic growth of more than $2 \%$ p.a. with hardly any rise in population, oil prices remaining at a high level, gas prices determined by market forces, increased environmental awareness in politics and among consumers, a growing trend to save energy and to improve energy efficiency, thoughts on the national level to use nuclear energy and expand the use of renewables. According to Van Oostvoorn and Boots, the Gas Directive can follow two different routes of implementation of the market conditions and thus might result in two 'extreme' impact scenarios. At the demand side, prices and volumes of natural gas consumption are important indicators for the effects of liberalization. In general, our calculations indicate that prices of gas will decline (and consumption will increase) as a result of market opening. With a full achievement of an internal gas market in 2010 it is expected that following effects will occur:

- Substantial lowering of natural gas prices in most of the seven mature EU countries,

- Convergence of gas prices across countries and between different consumers due to arbitrage facilitated by present and future trading,

- Decreasing profit margins of the gas companies,

- Substantial increase in gas consumption in bulk by continental EU countries and particularly in the power sector,

- Growing number of multi-utilities and convergence of the gas and electricity markets.

On the other side in case of a minimalist implementation of the Directive, the key objectives of the European Commission of an internal gas market will not be achieved, because Member States will focus primarily on protecting their stake in the national gas transmission and trade. Assessment of the price and volume effects is much more difficult in this scenario than in the scenario mentioned above. Briefly and tentatively we would expect the following effects:

- Limited structural changes in the EU gas industry,

- Moderate increase in gas consumption in bulk by continental EU countries,

- Continued unjustifiable price between countries and markets, especially for small household consumers (persisting dominance of national vertically integrated companies),

- Constant profits or a slight increase,

- Declining public support for liberalization process, in case of disappointing benefits expected from liberalization,

- Much smaller reductions of gas prices in the continental mature gas markets of the EU than in the FC scenario.

The major objective of the implementation of the EU Gas Directive is to promote 
increasing competition in the natural gas market, and to reduce gas prices for all customers and thereby to increase the competitiveness of (energy-intensive) European industries and economics. At the same time, substitution of natural gas for coal and petroleum-based fuels will improve overall energy efficiency and reduce $\mathrm{CO}_{2}$ emissions and other energy related emissions to the atmosphere. As mentioned before, some features of EUROGAS forecast and authors' forecast converge, but the situation is different. According to EUROGAS, the price of gas and oil should remain at high levels. At the end of 2008 it is obvious that a sudden drop in oil prices affected gas prices. Furthermore, it is undoubtedly assumed that the share of natural gas will grow in the primary energy consumption. In the future, the share of natural gas is expected to reach $30 \%$ of Primary energy Consumption. The authors' opinion is that gas consumption will grow, but with lower rates of growth. A breakpoint should occur because of the growth of world economy and reduced demand for oil and gas. One of the reasons might be the EU's turn towards more intensive use of renewable energy.

Figure 4: EU-27 natural gas demand outlook by sector

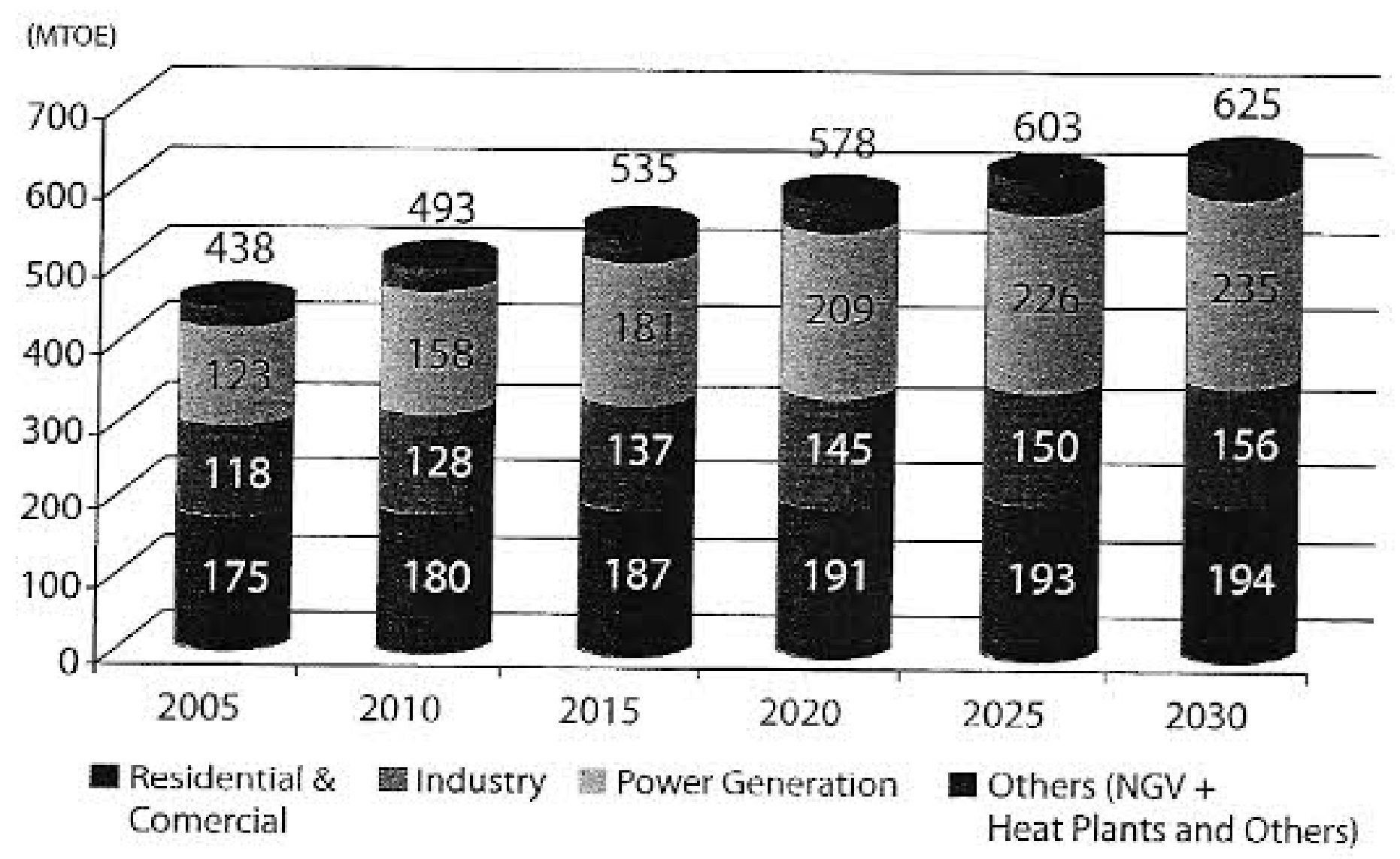

Source:http://www.eurogas.org/ (14.2.2009.)

In the residential and commercial sector, gas consumption has steadily risen in line with the expansion of the infrastructure and the associated rise in the number of gas users. Over past two decades, gas consumption has seen a $2.8 \%$ growth p.a. to $175 \mathrm{mtoe}$. Gas currently holds a market share of approx. $35 \%$, which makes it the market leader in this sector. In 2005, approx. 80 million homes in the EU-27 were supplied with gas. In the future, the population in the EU-27 will grow only moderately. In some countries it is even likely to decrease. Further market penetration in this market segment will also slow down considerably. The reasons are first of all that there is already a high market penetration in some major gas consuming countrics, and over time other countries will also reach gradual 
saturation in the residential and commercial market. Second, the low population density, settlement structures and topographical conditions in some countries set relatively narrow economic limits to greater market penetration. Further factors likely to limit gas demand include the improved energy efficiency of buildings, either through the implementation of better thermal insulation standards or the use of new heating systems with higher energy efficiency or, in some countries, increased competition as regards renewables. All these factors are likely to slow down volume growth quite substantially. By 2030, Eurogas expects gas sales to increase by only $0.4 \%$ to $194 \mathrm{mtoe}$ (Eurogas, 2008).

Regarding industrial sector, gas currently accounts for $33 \%$ of industrial final energy consumption (excluding industrial power stations) and is thus a major source of energy in this market. This sector is traditionally advanced in energy conservation. Given the strong international competition facing the European industry, the sector had to readjust and decrease its production costs. This explains the continuous investments necessary to renew production plants. This trend is likely to continue in the future. That means: the increase in energy consumption due to production developments will largely be cancelled out by efficiency-improving investments in plant modernization and replacements. In this sector, the price of energy plays an important role and only if natural gas can be supplied at competitive prices would gas be in a position to expand its market share and its sales volumes at the expense of oil and coal. On this assumption and with some support from emissions trading, gas sales to industry could be increased by some $1 \%$ to 156 mtoe until 2030 .

\subsection{The perspective of the gas supply}

Although Algeria, Norway and Russia will continue to be the prime suppliers to EU well into the next decade, substantial volumes can be foreseen to be supplied from a number of additional countries in Africa and the Middle East. In addition, the Caspian states could emerge as potential suppliers, but most likely not until after 2010. While Russia will probably struggle to increase their share in total exports to Europe over the next decade, North African suppliers and Norway will have every possibility to increase their market share taking into considcration their location close to markets with large growth potential (Italy, Portugal, Spain, Greece for North Africa and Germany and UK for Norway). Post2020, it seems probable that the Middle East will emerge as the main supplier (together with Russia), mainly through increased imports from Iran and Qatar. Looking at future European gas supply, there is no lack of options and gas reserves are available to serve the European gas market. Needless to say, the largest gas reserve holders worldwide - the Former Soviet Union and the Middle East - which account for $71.5 \%$ of the world total, are already supplying the Continent over distances in excess of $4000 \mathrm{~km}$ (Chabcrlie, 2007). In general, there seems to be widespread agreement that EU domestic gas production will diminish over time, mainly due to the declining British and Dutch gas production (Tönjes and Jong, 2007). The situation is different in Norway, where a further increase in gas production and exports is anticipated. Numbers for domestic EU production and Norwegian imports can be estimated with rather high certainty on the basis of operator forecasts, the availability of infrastructure and the knowledge of the reserve base that supports production. In the future, the oil price is expected to continue to be a major determinant for the gas prices. 
A crucial factor is the involvement of global oil production capacity relative to global oil demand. The dependency on the Middle East will increase, not only for oil but also for gas and, thereby indirectly for electricity supply (Kjärstad and Johnsson, 2008:877). The increased share of LNG in gas supply can be expected to lead to increased price volatility and to create an upward pressure on average local gas prices while increased competition both on the supply and the demand side (importers, transmission and distributors) should create a downward pressure.

It is difficult to forecast the major impact of liberalization on the EU gas supply market. There are various determinants which liberalization can not affect. According to forecasts of supply and demand and the creation of adequate measures of liberalization in the framework of the EU gas sector, negative surprises can be alleviated and some can be avoided. Some goals of liberalization can be achieved by short-term benefits, but long-term losses may occur. Therefore, the past situation, prospects of supply and demand, and external influences must be taken into account, in order to make liberalization more efficient.

\section{CONCLUSION}

Security of gas supply plays a vital role in the current discussions on the European energy policy. Concerns have risen with respect to sufficient investment, coming forward in order to meet demand and with respect to the use of natural gas as a mean of achieving foreign policy objectives. The European Union's gas markets are characterized by overall declining domestic production and increasing demand, and thus they will need to rely on more imports. Currently, much of import infrastructure to the EU-27 is under construction or planned. Because most of the EU Member States are dependent on gas, they are exposed to external influences. So it could be presumed that the effects of liberalization will be effective when the gas dependency of EU countries becomes reduced to a certain level. As a result, there will be a harder impact on prices or production and consumption of EU economies.

Increasing global gas demand, declining gas reserves in Europe, lower gas transportation costs, particularly for liquefied natural gas, requirements for diversified supply and higher gas prices, are all factors that will increase international gas trade. Viewed in the long run, the gas sector will play an increasingly important part in the supply of energy. Higher demand for gas will result in higher gas prices. If the energy dependence on gas becomes reduced and if the prerequisites for liberalization of the EU gas sector are fulfilled, a smaller price increase could be expected. In the short run, the global crisis and slowing down of the world economy will create reduced demand caused by price reduction of the oil prices. In the future, the population of EU-27 will grow only moderately. In some countries it is even likely to decrease. Further market penetration in this market segment will also slow down considerably. The reasons are, first of all, already high market penetration in some major gas consuming countries, while over time other countries will also reach gradual saturation in the residential and commercial market. Second, low population density, settlement structures and topographical conditions in some countries set relatively narrow economic limits to greater market penetration. 
Increase in the energy consumption duc to production development will largely be cancelled out by efficiency-improving investments in plant modernization and replacements. In industrial sector the price of energy plays an important role and only if natural gas could be supplied at competitive prices would it be possible to expand the gas market sharc and sales volumes at the expense of oil and coal. Because of "its green characteristics" and highly efficient application technologies, natural gas will be placed as a fuel of choice and will continue to make a growing contribution to energy supply of EU-27. As regards the future European gas supply, there is no lack of options, because gas reserves are widely available to serve the European gas market. The largest gas reserve holders, the Former Soviet Union and the Middle East countries, which account for $71.5 \%$ of the world total reserves, are already supplying the Old Continent. It is difficult to forecast the major impact of liberalization on the EU gas market supply. There are various determinants unable to affect liberalization. Some goals of liberalization can be achieved by short-term benefits, but long-term losses may occur as well. The past situation, prospects of supply and demand and external influences must be taken into consideration in order to make liberalization more efficient and thus to contribute to much lower gas prices.

\section{REFERENCES:}

1. Chaberlie, M.F. (2007), Gas Price Indexation and Strategies: A European Market Perspective, Presentation at $2^{\text {nd }}$ Asia Gas Buyers' Summit

2. Euractiv article (2008), Liberalization of EU Gas Sector (http://www.euractiv.com/en/energy/liberalisation-eu-gas-sector/article-171067)

3. Eurogas Position Paper (2008), The Role of Natural Gas in a Sustainable Energy Market

(http://www. eurogas.org/uploaded/Final\%20version\%20Annual\%20Report\%20as\%20 of $\% 20231208$.pdf)

4. Eurogas (2008), Eurogas annual report (http://www.eurogas.org/publications annualReport.aspx)

5. European Commission (2000), Opening up to choice-Launching the single European gas market, Luxembourg, Office for Official Publications of the European Communities

6. European Commision (2005), Energy sector inquiry - Issues paper, European Commission

7. http://www.eurostat.org/

8. Jackson, M., Harris, N. (2008), European Gas Trading (http://www.prospex.co.uk/PDF/47/European\%20Gas\%20Trading\%202008.pdf) 
9. Kjärstad, J., Johnsson, F. (2008), Prospects of European Gas Market, Energy Policy, Vol. 35 , Issue 2.

10. Proposal for Directive 2003/55/EC concerning common rules for the internal market in natural gas (2007) (http://www.energy.eu/directives/1_17620030715en00570078.pdf)

11. Tönjes, C., de Jong, J.J. (2007), Perspectives on security of supply in European natural gas markets, Working paper, Clingendael International Energy Programme

12. Urbanski, T. (2006), Energy production and distribution enterprises in the EU, European Communities: Statistics in Focus - Industry, Trade and Services, No. 31

13. Van Oostvoorn, F., Boots, M.G. (1999), Impacts of market liberalization on the EU Gas industry, The Shared Analysis Project Energy Policy in Europe and Prospects to 2020, Vol. 9. 


\title{
LIBERALIZACIJA PLINSKOG SEKTORA EUROPSKE UNIJE: UČINCI I PERSPEKTIVE BUDUCEG RAZVOJA
}

\author{
Ljerka Cerovic ${ }^{4}$, Marko Donadic ${ }^{5}, \&$ Tomislav Galović ${ }^{6}$
}

\section{Sažetak}

Rad obuhvaća područje liberalizacije europskog plinskog sektora i tržišta s aspekta njegovog budućeg razvoja. Kako je cilj europske energetske politike osigurati održivu, konkurentnu i sigurnu opskrbu energijom svojim potrošačima, europski plinski sektor uvjetovan je direktivama koje treba ispoštovati kako bi se taj cilj i ostvario. Prednost plina nad drugim energentima je u njegovoj ekološkoj čistoći pa je njegova konkurentnost na energetskom tržištu neupitna. U tom pogledu, europski plinski sektor osigurava kompetitivnost na tržištu energije EU. Naime, vitalnost unutarnjeg tržišta vrlo je značajna za konkurentnost Europe, budući da doprinosi povećanju investicija u infrastrukturu, kao svojevrsnoj potpori sigurnoj i efikasnoj opskrbi le uslugama na tržištu energije. U takvim uvjetima ekološki aspekti nisu nimalo zanemareni, štoviše, osiguravaju se i štite odgovarajućim instrumentima tržišta. Rad analizira recentne promjene u strukturi ponude i potražnje plina te posljedice vezane za poboljšanje konkurentnosti na plinskom tržištu EU. Analizira također ulogu rasta potražnje za plinom, zatim oporezivanje proizvodnje i trgovine plinom, ali i zavisnost europskog plinskog sektora o inozemnim dobavljačima. Liberalizacija tržišta plina vrlo je važno sredstvo za razvoj europskog gospodarstva u pravcu bolje učinkovitosti $i$ konkurentnosti na rastućem globalnom tržišstu. Implementacija europskih direktiva o plinu može se gledati kao finalni korak Europske unije ka ostvarenju unularnjeg plinskog tržišta. Glavni cilj je unaprijediti rastuću konkurentnost na tržištu prirodnog plina te reducirati njegovu cijenu za sve potrošače i time povećati konkurentnost energetski intenzivnih europskih industrija i ekonomija. Pritom rad razmatra izglede za vécom potrošnjom prirodnog plina ie buduće trendove europskog plinskog tržišta do 2030. godine, pod pretpostavkom da učinci liberalizacije mogu poboljšati funkcioniranje plinskog tržišta te tako doprinijeti većem smanjenju porasta cijene plina.

Ključne riječi: plinski sektor EU, liberalizacijaeuropskog tržišta plina, razvojeuropskog plinskog sekiora, energetska politika EU.

JEL klasifikacija: $L_{95}$

Dr. sc. Ljerka Cerović.docent na Ekonomskom fakultetu u Rijeci, E-mail: cerovic@efri.hr

Mr. sc. Marko Donadić, stručni suradnik za medunarodne odnose na Ekonomskom fakultetu u Rijeci, E-mail: mdonadic(a)efri.hr

3 Tomislav Galović, mlađi asistent na Ekonomskom fakultetu u Rijeci, E-mail: tgalovic@efri.hr 